\title{
Traditional and new ways in competence management: Application of HR analytics in competence management
}

\author{
Laura Johanna Karwehl ${ }^{1,2}$ (D) Simone Kauffeld ${ }^{2}$ \\ Accepted: 2 January 2021 / Published online: 27 January 2021 \\ (c) The Author(s) 2021
}

\begin{abstract}
This article within the magazine Gruppe. Interaktion. Organisation. (GIO) provides an overview of established and new ways in competence management, with a focus on the HR Analytics approach. Competence management has come a long way. Since the beginning of competence research in the 1970's technological progress and altering competence demands among employees have drastically reshaped the landscape of employment. Handling complexity and large amounts of information has become essential in order to keep up with developments of today's world. The globalised competition has fostered an increasingly intense 'War for Talents' under volatile circumstances. How can an organisation develop an anticipative competence strategy if there are so many variables regarding the future? Since digitalization and the evolving field of big data and predictive analytics enable new ways of information processing, new concepts for human resources management are required. The most prominent approach nowadays is a company-specific competence model that is derived from the organisational strategy. Employees are developed with regard to the competence strategy-even though it might turn out as too rigid to react flexibly to changing environmental conditions in a steadily faster global competition. We state that this process can be extended by a data-driven approach in order to support HR departments and achieve an improved rate of correct assessments for future HR developmental measures.
\end{abstract}

Keywords Competence management $\cdot$ HR analytics $\cdot$ Workforce analytics $\cdot$ Big data

Laura Johanna Karwehl

L.Karwehl@tu-braunschweig.de

Prof. Dr. Simone Kauffeld

S.Kauffeld@tu-braunschweig.de

1 Volkswagen AG, Wolfsburg, Germany

2 Institut für Arbeits-, Organisations- und Sozialpsychologie,

Technische Universität Braunschweig, Braunschweig,

Germany 


\section{Traditionelle und neue Wege im Kompetenzmanagement: Anwendung von HR Analytics im Kompetenzmanagement}

\section{Zusammenfassung}

Dieser Beitrag der Zeitschrift Gruppe. Interaktion. Organisation. (GIO) bietet einen Überblick über etablierte und neue Wege im Kompetenzmanagement. Der Fokus dieses Beitrags liegt auf dem Thema HR Analytics, sowie Chancen und Risiken in der Anwendung. Die Domäne des Kompetenzmanagements hat einen weiten Weg hinter sich. Seit dem Beginn der Kompetenzforschung in den 1970er-Jahren haben der technologische Fortschritt und veränderte Kompetenzbedarfe die Silhouette der Erwerbslandschaft drastisch verändert. Der Umgang mit einer stetig steigenden Komplexität und einer großen Menge von Informationen sind inzwischen unerlässlich geworden um mit den stetig voranschreitenden Entwicklungen der heutigen Zeit mithalten zu können. Der globalisierte Wettbewerb hat die Intensivierung des sogenannten „War for talents" unter unsicheren Umweltbedingungen begünstigt. Wie kann ein Unternehmen eine antizipative Kompetenzstrategie entwickeln, wenn so viele (mitunter unbekannte) Variablen zu berücksichtigen sind? Mit dem Aufstieg von big data und prädiktiver Analyse wurde der Weg für ein neues Verständnis von Informationsverarbeitung geebnet, von dem auch das Personal- und Kompetenzmanagement betroffen ist. Um sich im Wettbewerb behaupten und von neuen Technologien profitieren zu können, sind neue Konzepte notwendig. Heutzutage besteht der populärste Ansatz in einem organisationsspezifischen Kompetenzmodell, das wiederum von der Unternehmensstrategie abgeleitet wird. Mitarbeiter werden unter Berücksichtigung der internen Kompetenzstrategie entwickelt - auch wenn sich diese als zu rigide herausstellt, um flexibel auf veränderte Umfeldbedingungen in einem immer schnelleren globalen Wettbewerb zu reagieren. Die Autoren schlagen vor, dass dieser Prozess um einen datenbasierten Ansatz erweitert werden kann um HR-Abteilungen zu unterstützen und eine verbesserte Quote an HR-bezogenen Vorhersagen für die Zukunft zu treffen.

\section{Schlüsselwörter Kompetenzmanagement $\cdot$ HR Analytics $\cdot$ Belegschaftsanalysen $\cdot$ Big Data}

\section{About the relevance of competence management}

Since the 1980's competence demands among employees have increased (Erpenbeck et al. 2007) fostering a so-called 'War for Talents' (Michaels et al. 2001; Jochmann 2006). Even though the identification of future competence demands and the subject of competence management itself have received more attention recently (Vonken 2006) there still is no solution how to cope with a shift in competence demands fostered by the 4th industrial revolution ${ }^{1}$ (Berger and Frey 2016). A recent delphi study, conducted by Apt et al. (2016) showed a wide range among assessments and predictions regarding the current digital transformation which indicates that this phenomenon is of high societal relevance but also subject of high uncertainty at the same time. Arntz et al. (2016) state that besides the trends of upskilling and reskilling (that were already addressed by Berger and Frey (2016)) especially requalification and

\footnotetext{
1 The 4th industrial revolution is a phenomenon that is characterised by a high degree of adaptability, flexibility and versatility in an industrial context. It implies high individualization within products, the integration of customers and partners into the value chain, improved ergonomics and safety measures. On a digital scale it involves embedded systems and (partially) autonomous machines that communicate within highly complex structures and cyber-physical-systems, also known as the Internet of Things (IoT). For a more elaborate definition see Gabler Wirtschaftslexikon (2020).
}

further training will gain special relevance. Matching that, organisations consider their employees competence development as one of their essential strategies to remain competitive over time (Dirks 2016; Janssen and Leber 2015) and report a need for action regarding organisational education and training within the next five to ten years (Hammermann and Stettes 2015). One reason for the increasing relevance of Human resources development (HRD) is caused by the acceleration of economy and the shortened product life cycles at the same time that reduce the timeframe in which a skill is relevant to the market (Wildgrube 2018). This means that increasing complexity and rapidly changing competence demands within the economy no longer require an observing and reactive competence strategy, but rather a strategic advance planning and strategies for competence development under high uncertainty (Becker 2009). As this circumstance applies not only to graduates but also to longterm employees (Wildgrube 2018) and organisations across all branches (Patscha et al. 2017; Becker 2009). Compared to the high rate of changes that can be expected as consequences from the digital revolution and the future of work as a scientific phenomenon we face a gap. While the number of published papers about the future of jobs had their "all-time high in the 1960-1979 period" (Sanchez and Levine 2012, p. 399) and has decreased considerably since then, it can be assumed that the effects of digitalisation and technisation will have strong impacts on the job landscape as we know it (Frey and Osborne 2013; Vogler-Ludwig et al. 2016). The 
need for further investigations in the area of competence strategies in digitalized work environments is already addressed by Oberländer, Beinicke, and Bipp who state that "in today's organisations and politics, there is a growing awareness of the gap between existing and needed digital competencies of the workforce to master the challenges of the digitalised future at work" (Oberländer et al. 2020, p. 1). This finding is also supported by a World Economic Forum (WEF) study from 2016, that identified "large mismatches between the actual supply and demand of key-work related skills" (pp. 25-26) leading not only to mismatches between skill demand and supply nowadays, but also between today's skills and future skill requirements (World Economic Forum 2016). Furthermore, there is a perceived shift in competence demands, but there are only few studies that focus on the relation between new technologies fostered by the 4th industrial revolution and changing competence and qualification demands which are moreover based on company surveys (Arntz et al. 2016).

Such changes within the job landscape and demands among certain professions have a serious influence on various facets of work environment. To meet the constantly changing competence demands across multiple branches organisations have to acknowledge the relevance of a strategic competence development across different industries and functions of employees over a whole period of employment (Becker 2009; Decius and Schaper 2017; Wildgrube 2018; World Economic Forum 2016) even though there is only comparatively little empirical evidence about strategic problem solving in organisations (Becker 2009). The employees perspective is specifically relevant to strategic competence development since "each worker has an individual set of competencies and each job position requires a combination of different competencies based on the $\mathrm{KSAO}^{2}$ concept or its variations" (Oberländer et al. 2020, p. 5). The employees change in status from being listed as an expense factor to human capital and strategic advance in innovation capabilities has shifted the requirements to human resource management to a more integrated and strategic approach (Müller 2006). One approach to address employees competencies and skills as strategic competitive advantage is the Resource Based View (RBV). The RBV serves as a strategic approach within organisations and focuses on using and developing competencies already present instead of contemplating on the practices primarily. It highlights the importance of competence and skill development as it emphasizes on the relevance of employees as a source for organizational success (Berthel and Becker 2010; Wildgrube 2018). The $\mathrm{RBV}$ can also be used for competence demands in complex and changing environments as it is possible to mon-

${ }^{2}$ KSAO stands for Knowledge, Skills, Abilities and Others (Campion et al. 2011). itor certain activities that are relevant e.g. to a company's strategic goals or its long-term success. By identifying the relevant activities an organization is given the possibility to prepare for system changes in advance and thus to avoid a mere reaction to environmental changes (Becker 2009). Still, the RBV primarily takes differences in resources into account to explain divergent performances among companies. A more holistic approach for the strategic orientation of companies is provided by the Competence Based View (CBV). It extends the RBV inasmuch as explaining different degrees of performance based not only on available resources, but also based on the individual set of competencies within a company that activate the available resources (Müller 2005). By considering the competencies within employees as a strategic competitive advantage, it contains not only the resource-based perspective but connects it to a strategic point of view (Becker 2009). The economic and social changes of the past years lead to the conclusion that a company must hold a solid understanding of its competence demands and its employees skill profiles especially in hindsight to changing future competence demands initiated by disruptive system changes (World Economic Forum 2016).

\section{Latest developments in competence management}

The organizational psychology as a branch of psychology addresses psychological and social effects of individuals in a work-related context as well as certain related factors, e.g. market, organizations, working life, and human resources (HR) (Schlick et al. 2010; Tewes and Wildgrube 2016). The field of competence research as part of organizational psychology was introduced no later than 1937 by David C. McClelland through a publication titled "Testing for competence rather than for intelligence" (McClelland 1973). Only a few years after that publication a large shift in skill and competence demands began, caused by changing work environments and technological progress (Arnold 2010; Erpenbeck et al. 2007). Moreover, along with a modified understanding of work and technological possibilities it has been argued that the concept of mere qualification should be replaced by the broader competence term (Arnold 2010) to adapt to increased complexity. The current developments in the fields of work and competencies create a complex and nevertheless essential tasks for HR departments: As Erpenbeck and Rosenstiel (2005) point out, a company's market value is predominantly determined by its human capital and therefore by the individual set of competencies every employee holds. But given the increasing speed of globalization and technological development on the one hand, and the decreasing time in which employees can make use of 
their competencies due to the former, it becomes clear that the strategy for HRD can no longer be focused on present developments, but rather has to strategically anticipate competence demands for the future. The main task for HRD is no longer based on identifying and providing the right qualifications for employees, but also to ensure long-term success on the global market by anticipating relevant fields in innovation, deriving relevant competencies and providing according measures. The scope is not so much to extend the monitored time frame but rather to cope with a more volatile interplay of future variables. The increasing uncertainties in future social and technological developments can be met by measures of strategic foresight (Mietzner et al. 2017). Due to the increased relevance of strategic orientational knowledge in a dynamic environment various organisations have started to build up departments for trend detection, corporate foresight and futurology (Müller and Müller-Stewens 2009). Departments like these have become important because even the RBV fails in explaining how advantages in resources can be maintained over time (Butschan et al. 2017) as environments have begun to change faster and more drastically fostered by technological progress. The demand for a future-oriented focus is impeded further by the complexity of the HRD and competence development field with its many influential factors and superordinate components. For example the characteristics and educational level of a society, the legal system and the economic condition and status have a strong impact on how a company's HR processes are shaped (Becker 2009; Klimecki and Gmür 2005). Moreover relevant qualifications can take place within a standardized format, such as an industrial training, or in an unstructured manner, e.g. during working activities (Schelten 2004). As whereby the latter is hard to measure by competence surveys (Ballot et al. 2006), they are rather measured by knowledge- or competence tests. With standardized human resource information systems (HRIS) human resource professionals most likely will not be able to identify latent competencies among employees because there are no formal verifications. Still one of HRs major goals is to ensure that employees and their respective current and future competencies contribute to the strategic goals of the organisation (Asgarian and Feuersinger 2017). The questions remaining must be: a) how can organisations nowadays receive an accurate assessment of the current competence portfolio available b) and how can it be matched with future developments in order to identify competence gaps? The most prominent answer will likely be: improved competence models.

\section{Competence models}

It is well known that competence models have a number of positive impacts on organizational- and human resource development. For example, Kauffeld and Grote (2019) already argued that competence models can not only depict the current competence demand, but also relevant future competencies. In order to understand the challenges competence management is currently confronted with, it is important to have a closer look at the structure and working mechanisms of competence models.

As Sanchez and Levine point out, "competency modelling includes an effort to understand the organisation's mission, values, strategy and goals" (2006, p. 84). In this manner, a company's competence model is often aligned with the organisational strategy and derives its own strategy and goals from it (Kauffeld and Paulsen 2018; Scholz 2018). The relevance of strategic alignment distinguishes competence management and its related competence models from the field of job analysis. While the primary goal of job analysis is to understand demands to certain position and making the assignment measurable, competence management contains a more holistic approach in trying to emphasise on presumably strategic, behavioural themes in the performance of work assigments (Sanchez and Levine 2009). Another characteristic of competence models is the measurable and comprehensible description of competencies that are required for a successful job performance (Sauter and Staudt 2016). To serve the strategic approach of competence models, a regular acquisition of desirable competencies and the involved demands for qualification is necessary (Fredersdorf and Glasmacher 2010) that can be met in form of a requirement analysis (Becker 2011; Solga et al. 2011). From an individual perspective a sound competence management ensures and improves the employability within an organization and employees career management (Paulsen and Kauffeld 2019).

In order to receive valid strategies for competence development, competencies should be explained precisely, e.g. with an exact definition, and different levels of expertise (Kauffeld and Grote 2019). Furthermore, they should be linked to specific behavioural anchors that describe (un-)successful behaviour. Through the translation into behavioural patterns competencies become observable, measurable and assessable (Sauter and Staudt 2016). Since organisations often have a huge amount of defined competencies at their disposal and the complexity is increasing steadily, a (poly-) hierarchical structure (Paulsen and Kauffeld 2019; Schmidt and Kunzmann 2006) or clusters (Campion et al. 2011) can help improve the handling of competencies over different job families. Given a solid foundation of interconnected competencies with linked behavioural anchors enable HR professionals to determine 
competence gaps and identify according qualifications (Braun et al. 2008). Further characteristics and references for the development of competence models can be retrieved from Campion et al. (2011), who define 10 features of competence models, such as the distinction between top performers and average performers or the majorly chosen top-down design instead of the bottom-up approach. A characterisation of competence models is also provided by Paulsen and Kauffeld (2019), as well as useful tips for establishing environmental conditions that foster a successful implementation of competence models in organisations.

Apart from structural conditions, HR's part also includes establishing a framework that demands, promotes and allows the development of relevant competencies (Scholz 2018). That also implies that organisations have to adapt their competence management systems in hindsight to external environment developments. An approach on how external developments, e.g. the effects of technological progress can be implemented into competence modelling is the Kompetenz-Navi (Paulsen and Kauffeld 2019; Kortsch et al. 2016). The organisation-specific competence models are filed within the system based on which the competence diagnosis generates surveys and evaluations automatically (Kortsch et al. 2018; Paulsen and Kauffeld 2019). This process ensures a continuous monitoring of the target-actual-ratio to improve strategic recommendations for action. Approaches like the Kompetenz-Navi indicate that HR experts have recognised the spaces of opportunity for improvement brought along by technological progress.

Still, the question remains how reliable competence portfolios shall be retrieved if HR data cannot precisely recognize if an employee has a certain competence or not (Schmidt and Kunzmann 2006). Questions like these are based on the blurry line that divides competence modelling and job analysis (Sanchez and Levine 2012) and represent only one of the various challenges competence management has to overcome in order to add strategic value to competence development in the upcoming times.

\section{Limits of traditional competence management systems.}

There are different reasons why HR departments are having a hard time establishing themselves as 'fit for the future':

1. HR analyses usually work by retrospective approaches to recognize patterns whereas the challenge in times of digitalization lies in assessing what is likely to happen in the future (Levenson 2018). This is especially relevant when it comes to increasing speed in environmental changes. As Patscha et al. (2017) state, yet there is no comprehensive prognosis approach for a future demand in profes- sional experts that takes demographic, regional and industry-specific developments into account.

2. At the same time, current research lacks representative studies on an ongoing digitalization and automation and their effects to work-related tasks and competence demands among employees (Arntz et al. 2016). Smith (2016) found out that the majority of the surveyed participants expect a shift in work-related tasks within the next 50 years, along which support for employees is one of the high hopes regarding the digitalized workplace. As digitalization often involves higher degrees of complexity, at the same time it offers various options of support within those complex environments (Kagermann 2014). Workers for example can be guided by digital systems when operating machines. While ubiquitous information allows workers to improve their competences and skills the importance of qualifications regarding the assisted tasks decreases at the same time (Apt et al. 2016).

3 . Even though the phenomena of globalization and digitalization have been foreshadowing at the horizon, (Scherer 2002) finds that most companies still do not have a suitable concept to support the digital change. We know that competence ontologies can serve as useful tool to allocate employees following shifted competence demands (Braun et al. 2008), still most HR departments can only give vague estimations about changing workplace requirements (Apt et al. 2016). However, especially with regards to a shift in competence demands and modified requirements in education and training, assessing future competence demands as precisely as possible is essential. Becker (2009) states that the qualifications gained before entering working life are no longer sufficient to react appropriately to disruptive system changes. If there is no strategic orientation available, employees are required to react to customer demands proactively on their own (Scholz 2018). As system conditions are changing faster and becoming harder to predict, the same demand as for employees goes for competence management systems (Kauffeld and Paulsen 2018). A miscalculation in available and future competencies can be dramatic for a company's survival on the market because competence shifts often involve huge developmental efforts and can take years instead of months (Asgarian and Feuersinger 2017). So, it is important on the one hand to interpret signals for system changes correctly at an early stage, while on the other hand keeping a reliable overview on the available competence and skill portfolio-including those that are not filed in a HR database yet. In the words of Momin and Mishra: Finding and "effectively use[ing] latent competencies and skills of employees has always been the ultimate task for HR managers" (2015, p. 258). 
Competence management should consider the shifting focus from retrospective to anticipation, demographic changes, the impacts of digitalisation and technisation on future work environment and be able to derive future competence demands from it. What can HR do considering the variety of challenges on different levels it is currently confronted with? How can HR make use of the benefits of digitalization and globalization to enable employees within their field of expertise while ensuring the company's survival within global competition? An approach is given by Hamilton \& Sodeman who state that "to remain relevant, HR must begin to analyse combinations of multiple sources of data-particularly data gathered outside of the traditional HR purview-in order to evaluate employee performance more effectively and, by extension, improve firm performance as well as guide how firms can help its knowledge stars to flourish" (Hamilton and Sodeman 2020, p. 86).

\section{New approaches to competence strategies}

Up to this point we have seen that companies are facing a rapidly changing, highly uncertain future in which they have to develop a strategy to ensure survival on the market. As already mentioned, the technologies and possibilities subsumed under the term '4th industrial revolution' bear various possibilities but hold some challenges as well. For instance, new technologies come with the promising prospect to gain improvements in efficiency and effectiveness within the production branch. Yet, before profiting from the impacts of digitalization new competencies on how to handle the new technologies and devices have to be built up within the organisation (Butschan et al. 2017). Furthermore, the possibilities and promises new technologies hold will not be the answer to all the challenges HR departments in companies are currently confronted with. Even though there are numerous possibilities, it has to be analysed in how far IT systems and solutions can be used for competence management and development (Paulsen and Kauffeld 2019). In times of global competition it is harder than ever to remain top player in a field that is constantly entered by new players with varying business models. The only way to secure ones leading position in a market is not by imitable business models or products but by the individual proficiency of the human capital management (Momin and Mishra 2015). In their publication "What it will take to fix HR" Benko and Volini (2014) define premises for an increased shift speed in HR: a) Find the field where most strategic value is created and focus on it, b) Ensure HRs relevancy by recalibrating and reskilling where necessary, c) induce quantitative measures, and d) revaluate the current distribution of tasks. The solution seems to be an ap- proach that improves data handling in current systems and maximises the benefits of digitalisation but at the same time takes individual characteristics and conditions into account, since competence management still plays an important role in future HR (Nienaber 2007). But how can we use data to improve human performance further? So far, most companies have been analysing HR data within HRIS in form of queries to e.g. calculate KPIs for reporting. But-referring to the Gartner Analytic Ascendary Model-beyond hindsight, there are two further levels of data analysis (Eliott 2013). The next step in data analysis is called diagnostic analytics or insights. The goal of diagnostic analytics is to scan unstructured documents by one or multiple designated search terms that can be linked to each other. The relevant documents are identified but have to be evaluated manually. The most advanced level of data analysis is the level of foresight in Gartners model. It tries to recognise patterns in data, the approach varies depending on the structure of the given dataset. Other terms for this level of data analysis are data mining, knowledge discovery in databases or predictive analytics (Strohmeier 2017). Predictive analytics can be understood as a sub category of data science and as Waller and Fawcett point out although it "is related to many longstanding quantitative approaches, it stands as distinct from each" (2013, pp. 79-80). Considering the current developments described earlier, the complex level of predictive analytics is most desirable to evaluate business strategies.

Yet, the opportunity to conduct such analysis is bound to an appropriate set and amount of data that have to be given. Strohmeier (2017, p. 341) explains that-even though there are various approaches for a definition and there is no consistent understanding — so called 'big data' is given, if the data set meets the criteria of the 3-V-model: volume, variety and velocity. There are no sharp definitions to check whether the data matches the criteria but as a guideline Strohmeier (2017) recommends the following: The criterion of volume is met if data can only be stored and analysed if new storage capacities and techniques of analysis are applied. The criterion of variety requires the presence of various level of structure in data: structured, semi-structured, and unstructured. The criterion of velocity applies to two sub-instances, the speed of data reception and data output. Both instances can be processed in historically, in near-time or real-time, whereof big data requires the latter. The idea of big data is the continuous analysis and search for patterns within a limited set of data (test sample) by software. Those patterns are used to learn interrelationships between different variables and develop corresponding algorithms, which are then applied to a larger set of data in order to determine linkages and identify precise predictors (Hamilton and Sodeman 2020). 
This process is called machine learning and even though it offers countless opportunities and can support humandriven data analytics some precautions have to be met in order to receive reliable results. Generally it can be said, that a machine learning algorithm can be just as good as the data sample it was trained on. If there is some error, e.g. overfit or algorithmic bias within the learning sample the algorithm will not be able to perform correct prognosis within the final data set (L'Heureux et al. 2017). An overfit among data occurs when the test sample contains correlations between variables that are of random nature but are interpreted as relevant by the algorithm. The larger the test sample, the bigger is the probability that some random correlations are included. Algorithmic bias can have two sources of error: a) the data set was not sufficient and did not consider relevant criteria so that the algorithm leaves out relevant information and b) the test sample is complete but contains some form of already inherent bias produced by humans (Dickson 2018; Hamilton and Sodeman 2020). For example, Crosman (2018) and Singer and Metz (2019) give examples in which a facial recognition software was found to identify faces of other than Caucasian ethnicity wrong or not at all significantly more often. In 2018 it became public that Amazon had worked on a recruiting tool that systemically rejected women from technical jobs because the present share of women in tech jobs at amazon was so rare (Reuters 2018).

But how can the emerging trend of big data be applied to the respective fields of HR like competence development? According to Strohmeier (2017) most companies do not have big HR data according to the definition mentioned above, even though the data pool in HR is growing continuously and increasing in variety and velocity. As huge parts of our lives become digitalised the possibilities to collect data relevant for HR increases. Additional information to the standardised employee forms can be retrieved from e.g. social media, video analytics and the internet of things (IOT) (Hamilton and Sodeman 2020). However, the trend towards big data in HR does not automatically involve a benefit or advance in knowledge. To make sense of the huge and complex amount of data in HR great efforts have to be undertaken (McIver et al. 2018; Strohmeier
2017). Even though Jatobá et al. (2019) argue, that the establishment of artificial intelligence, such as big data or predictive analytics, is essential for the effectiveness of HR departments, it has to be considered that even thoroughly planned projects with big HR data will only be able to offer a partial supply of information (Strohmeier 2017) which, on one hand means that a sufficient information supply on big HR data analysis in connected to a great effort. On the other hand, HR departments have been undergoing massive changes lately and are strongly impacted by trends of data analytics that offer a new role within the organization (Jatobá et al. 2019). There are voices that say the concept of big data in HR is relatively new (Marler and Boudreau 2017), whereas the report "Using Workforce Analytics for Competetive Advantage" by the Society for Human Resource Management (SHRM) Foundation points out that HR departments are the rookies among the departments who have been making use of advanced analytics for some time already (SHRM 2016) who already missed the big data train. Since the impact of big data in HR seems to be far-reaching there should be some literary evidence.

The first, quite self-explanatory, insight on HR analytics literature is that information systems literature and information management contain more information on big data than HR and management literature (Calvard and Jeske 2018). In 2019 Jatobá et al. performed a literature analysis on Artificial Intelligence (AI) and HR and found 32 publications in the data base of the Library of Online Knowledge. Secondly, there seem to be multiple terms for big data analytics in HR: HR and human resources analytics, workforce analytics, people analytics and talent analytics, from which HR analytics seems to be the term most frequently used (Marler and Boudreau 2017, p. 6, 2017, p. 7; McIver et al. 2018, p. 397).

\section{HR analytics}

According to Bassi (2015) even with respect to a better understanding on the second level of data analysis (insight) identifying human drivers of business results remains es-
Fig. 1 Numbers of publications on "HR", "People", "Human Resource", "Workforce" and "Talent" Analytics

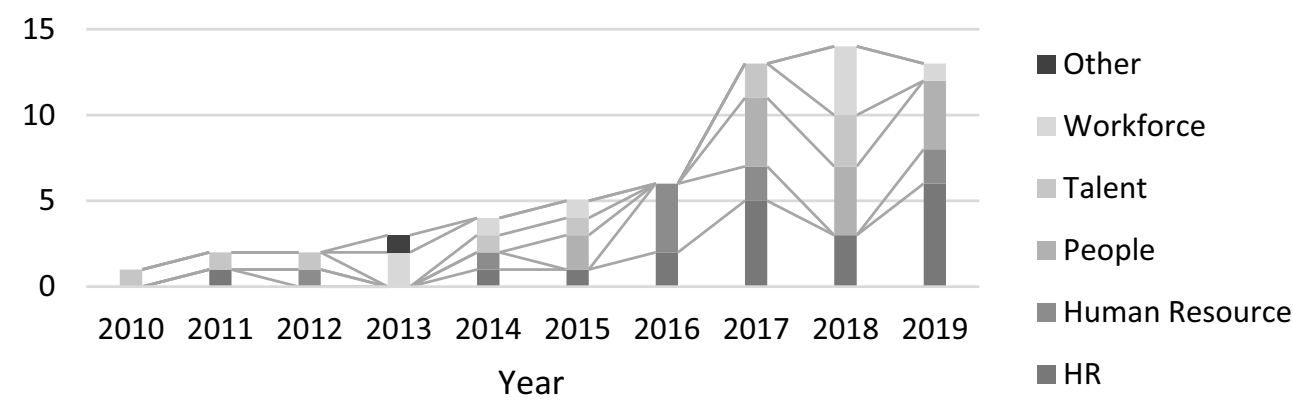


Table 1 Most prominently discussed aspects of HR analytics

\begin{tabular}{|c|c|c|}
\hline Title & Central question & Key aspects \\
\hline $\begin{array}{l}\text { Business cases of HR } \\
\text { analytics }\end{array}$ & $\begin{array}{l}\text { What is the value added by } \\
\text { data analytics? }\end{array}$ & $\begin{array}{l}\text { HR analytics can add value on various levels: From improving outcomes on in- } \\
\text { dividual level over supporting management with evidence-based approaches for } \\
\text { strategic decisions to competitive advantage for the organisation as a whole }\end{array}$ \\
\hline $\begin{array}{l}\text { (Infra-) structural require- } \\
\text { ments on big data in HR }\end{array}$ & $\begin{array}{l}\text { What environmental con- } \\
\text { ditions does it take to start } \\
\text { with HR analytics? }\end{array}$ & $\begin{array}{l}\text { Organisations should formulate a strategy and mission and ensure the manage- } \\
\text { ment's approval. On an infrastructural level consistent data has to be available, as } \\
\text { well as the capacities to store and analyse said data }\end{array}$ \\
\hline $\begin{array}{l}\text { Skill requirements among } \\
\text { big data in HR }\end{array}$ & $\begin{array}{l}\text { What do we need to know } \\
\text { in order to start with HR } \\
\text { analytics? }\end{array}$ & $\begin{array}{l}\text { Experts that engage in HR analytics should have three major competencies: Pro- } \\
\text { found HR knowledge, skills in data analytics and interdisciplinary teamwork }\end{array}$ \\
\hline $\begin{array}{l}\text { Approaches of HR big } \\
\text { data analytics on individ- } \\
\text { ual performance }\end{array}$ & $\begin{array}{l}\text { How can individual perfor- } \\
\text { mance be used for strategic } \\
\text { corporate goals? }\end{array}$ & $\begin{array}{l}\text { By collecting individual performance data a task-based information data base can } \\
\text { be created that can be used to identify skill and competence profiles of successful } \\
\text { job holders and improve employee allocation throughout the organisation }\end{array}$ \\
\hline $\begin{array}{l}\text { Use case-related prerequi- } \\
\text { sites on big data in HR }\end{array}$ & $\begin{array}{l}\text { What kind of questions } \\
\text { should be tried to answer } \\
\text { with HR analytics and } \\
\text { why? }\end{array}$ & $\begin{array}{l}\text { Suitable questions vary from mere reporting for an improved output to strategic } \\
\text { decisions regarding future business cases. The choice of issues to be worked on } \\
\text { depends on the effort an organisation is willing to undertake in order to collect, } \\
\text { analyse and evaluate data }\end{array}$ \\
\hline $\begin{array}{l}\text { Developmental signals of } \\
\text { big data in HR }\end{array}$ & $\begin{array}{l}\text { Where can HR analytics be } \\
\text { located in the field of added } \\
\text { value and innovation? }\end{array}$ & $\begin{array}{l}\text { Even though its impact often can't keep up with other analytics departments, the } \\
\text { idea of HR analytics is not exclusively new. Some issues HR analytics tries to } \\
\text { answer on the reporting level have already been examined by various experts, } \\
\text { while the predictive level offers wide ranging potentials for innovation }\end{array}$ \\
\hline $\begin{array}{l}\text { Employee-related precon- } \\
\text { ditions for a successful } \\
\text { application of HR big data } \\
\text { analytics }\end{array}$ & $\begin{array}{l}\text { What does it take to im- } \\
\text { plement and apply HR } \\
\text { analytics successfully on } \\
\text { the employee-side? }\end{array}$ & $\begin{array}{l}\text { Organisations should inform employees transparently about the volume, motive } \\
\text { and results of data to be collected and ensure that it is used in everybody's best } \\
\text { interest. A transparent depiction of competencies can improve satisfaction and } \\
\text { output }\end{array}$ \\
\hline $\begin{array}{l}\text { Ethical implications for } \\
\text { implementation of HR } \\
\text { analytics }\end{array}$ & $\begin{array}{l}\text { What to consider when } \\
\text { thinking about implement- } \\
\text { ing HR analytics? }\end{array}$ & $\begin{array}{l}\text { Big data analytics in an organisational context is just becoming a prominent issue } \\
\text { in public awareness. As technology develops much faster than organisations are } \\
\text { able to adopt rules for the application of it, this is likely to become a heated field } \\
\text { of interest }\end{array}$ \\
\hline $\begin{array}{l}\text { Requirements in data } \\
\text { security }\end{array}$ & $\begin{array}{l}\text { Can HR analytics and data } \\
\text { security work together? }\end{array}$ & $\begin{array}{l}\text { Principles of data security suggest a contradiction towards the goals of big HR } \\
\text { data. Bringing the two diverging interests into balance is a responsible task that } \\
\text { can flourish in a symbiotic relationship. Codes of conduct can help establishing } \\
\text { trust and guidelines }\end{array}$ \\
\hline $\begin{array}{l}\text { Potential perspectives on } \\
\text { HR analytics in compe- } \\
\text { tence management }\end{array}$ & $\begin{array}{l}\text { Where can HR analytics } \\
\text { help to improve compe- } \\
\text { tence management? }\end{array}$ & $\begin{array}{l}\text { For the field of HRD there are numerous options for beneficial use cases that } \\
\text { include a strategic advantage on different levels in different functions. From pre- } \\
\text { assessing candidates in recruiting to mapping shifted competence demands and } \\
\text { developing anticpative competence strategies in HRD }\end{array}$ \\
\hline
\end{tabular}

pecially defying. This is exactly where HR Analytics is attempting to bridge the gap.

To gain a closer impression on the phenomenon of HR analytics we conducted a lean literature research. We searched the Web of Science, Conference Proceedings (5 million papers from over 110,000 conferences since 1990), Current Contents Connect (Bibliographic information from over 8000 journals and 2000 books) and Inspec (an IET database with nearly 4000 scientific journals, 2000 conferences and various books, reports and dissertations). The databases were searched for publications between 2010-2019 and containing the terms "Human Resource(s)", "HR", "Workforce", "People" or "Talent" in conjunction with the word stem "Analy*", which can either mean "Analytics" "Analysis" or "Analyse" as a title. We received a total of 82 results that were further analysed. We found 19 publications that contained the relevant terms but were assigned to different subjects. From the remaining
63 publications we found the following ranking: Nine articles used the term "Workforce" analytics", 10 dealt with "Talent" analytics, whereas 11 publications were assigned to the term "Human Resource" analytics. The more general term "People" analytics applied to 14 publications and, along with the findings of Marler and Boudreau (2017), the most frequently used term we found was "HR" analytics (18 counts). In accordance to our results we will too use the term HR analytics to describe the field of big data in HR in the following. Also in line with Marler and Boudreau (2017) we found that there seems to be an evolving trend on the subject of HR analytics. The numbers of publications increased from 1 in 2010 to 20 in 2018 and had a little decrease to 17 in 2019 (Fig. 1).

The multiple terms for HR analytics determine that there are also various approaches to define it. Since its first appearance in HR literature between 2003-2004 (Marler and Boudreau 2017) there were different attempts varying in 
depth and complexity. The first available characterization in HR literature is given by Lawler III et al. (2004) who state that analytics in HR are not really own measures but rather the application of statistical techniques and experimental approaches in order to reveal the "causal relationship between particular HR practices and such performance metrics as customer satisfaction, sales per employee and, of course, the profitability of particular business activities" (p. 31). Bassi (2015), as well as Momin and Mishra (2015) grant HR analytics more stand-alone characteristics and scope by labelling it an evidence-based approach to improve decision making that contains tools and technologies from business intelligence, ranging from reporting of HR metrics up to predictive modelling. A comprehensive overview on the characteristics of HR analytics is given by Marler and Boudreau (2017): Compared to HR metrics, HR analytics uses an advanced level of HR data analysis, as it uses information technology to collect, manipulate and report data from different internal functions and external data. Besides its purpose to support in people-related questions it is particularly aimed at linking HR decisions to business outcomes and performance. Looking at the available definitions for HR analytics it can be summarized that the aim of HR analytics is to improve individual and organizational performance by using big HR data and statistical analytic methods on all levels from reporting to prediction. According to this understanding HR analytics seem to pursue the same target as todays competence management. The novel concept of HR analytics lies in the approach of advanced data analytics using data from different sources and of different granularity to create new insights and recommendations for action. Even though HR analytics has many benefits such as enhancing HRs credibility (Bassi 2015) or a business-centred use case that is likely to be relevant for decision-makers (Rasmussen and Ulrich 2015) there is a number of questions for organisations interested in gaining competitive advantage. A more detailed review will be provided through the following pages, structured by the most prominently discussed aspects in current literature (Table 1).

\section{Business cases of HR analytics}

Looking at the organisational landscape it is striking that the examples for a successful implementations of HR analytics in organisations are little (Staritz and Biemann 2018) - and that despite the fact, that the majority of managers surveyed by Deloitte sees HR analytics as a very important or important trend for the future (Deloitte 2019). Besides the target effect of improving outcomes for the organisation as a whole, but also for individuals in it, HR analytics can reveal some additional insights that can help to reduce workloads (Bassi 2015). To implement HR analytics within an organisation possessing the necessary data (that are often highly specific in HR topics) is not enough. To make sense of big HR data Rasmussen and Ulrich (2015) point out that defining a business challenge to tackle is essential if HR wants to create value adding, insightful results. A business case-centred approach is also useful to reach HR analytics goal to support management with an evidencebased approach for strategic decisions (Bassi 2015). As data analytics can be seen as an integrated part of an overall framework (Rasmussen and Ulrich 2015) it is particularly important to embed it into the organisational network precisely. Still, satisfying this premises does not automatically ensure a realisation of gained results and recommendations for actions (Boudreau and Cascio 2017), which might have reasons on different levels. Retrieving insights from causal analysis and other advanced approaches to HR analytics sometimes fail to meet the expectations which might be because analytics in HR have evolved over the past years, while the development of respective methods and models seems manageable (Cascio and Boudreau 2015). Nevertheless, according to Staritz and Biemann (2018) HR analytics involve a number of benefits for various parties, whereat it can be differentiated between implicit and explicit benefits. Implicit benefits are caused by the application of the process itself and involve improved competencies for HR professionals, involvement for employees and customers, and cultural change for the organisation as a whole. Explicit benefits are gained by the successful performance of analysis and implementation of results. They contain satisfaction and higher product quality on the customer side, an increased quality of results and faster completion of tasks for HR departments, a higher degree of transparency for employees and competitive advantages on an organisational level.

\section{8 (Infra-)structural requirements of big data in $\mathrm{HR}$}

An essential part of enabling HR analytics within a company is the availability of an organisational strategy and a future mission. The strategy has to be described in a detailed, well-founded manner or otherwise it will be difficult to derive deviations from current to target state or even to derive relevant competencies at all. If these conditions are met a closer look at the infrastructural level can be taken:

When gathering data for big data analysis an initial problem will likely be that the data required is either inconsistent or not available at all (Deloitte 2017; Staritz and Biemann 2018), or it is being stored in different data bases because they are assigned to different tasks (Cappelli 2017). Therefore the effort that has to be undergone in order to 
collect the data, adjust it from errors, harmonise different labels and bring together data from different sources is much higher than in conventional data warehouse usage (Strohmeier 2017). While the diverse pools for data are already a challenge for analysts on operational questions, the challenge of data analytics in competence management is even more complex due to the latent character of competencies. The additional step from observing an operation and linking it to a competence anchor which is again linked to a competence has to be considered in every use case. The multi-layered sources with multiple interconnections and complex algorithms further complicate an easily feasible solution for the ratio of data collection and analysis. The more data is collected and stored the more advanced analyses and approaches can be tested for. On the other hand, more data does not always mean better data which is why data sources should be selected carefully and be checked for their benefit regularly. At the same time, the increasing complexity of more and more interwoven knots of information in analytic systems bear the risks for undetected errors and data accidents and complicate a transparent solution for the management of sensible data. Globalisation poses a special challenge in terms of HR analytics and competence management. As competence is a fuzzy term with user-specific connotations it might turn out difficult to monitor a consistent state of competence holders if the words used to describe this competencies already differ.

Finally, successfully implementing HR analytics and benefiting from its insights demands not only possessing the necessary data and the capacity to store and analyse them. It also requires approval by the management, the employees and it includes demands regarding employees skills and competencies. Regarding the acceptance of employees it is important to consider their concerns, e.g. invasion of privacy, seriously and assure a transparent, ethically compliant collection of data (Hamilton and Sodeman 2020). In hindsight to an improved competence management, organisations have to ensure that not only the relevant performance data is available, but also that it is provided with some context. Assessing if an employee possesses a skill or competence (or rating the level of expertise) can rarely be identified by a simple binary 'yes-or-no' question so the mere analysis of operational performance data will most likely not be sufficient to deliver valuable insights. The RBV and other strategic frameworks can for the one thing help to reveal costs and benefits regarding the implementation of HR analytics as well as an estimation for the expected degree of return in competitive advantage and valuable insights (Calvard and Jeske 2018).

\section{Skill requirements among big data in HR}

As Butschan et al. (2017) identified human capital, i.e. employees and their individual set of skills and competencies, as prerequisite for success in times of the 4th industrial revolution the trend of HR analytics shows the defiance of developing employees fast and at the same time profoundly enough to keep up with the challenges of digitalisation. To handle big HR data and interpret the results the right way employees do not only need to have specific knowledge about HR but also possess certain skills like different levels of data analysis and multivariate models or quantitative data collection, preparation and analysis (Marler and Boudreau 2017). Both aspects can be seen as core competencies for HR analysts but belonged to different roles and job descriptions in the past. As building up new core competencies takes time a rush in building up HR analytic teams is likely to be accompanied by insufficient practical knowledge, especially when it comes to recognizing predecessors of critical failures (Calvard and Jeske 2018) that can have far-reaching impacts. In 2017 Marler and Boudreau found that the lack of analytically skilled HR professionals was the most frequently named reason for the scarce implementation of HR analytics which is likely to intensify when it comes to data analytics beyond the level of reporting. This rate is likely to remain at a low for some time since especially in fields as human resource development and competence management a keen understanding of relevant constructs is essential for meaningful analysis. The shortage in capable HR analysts is intensified even more by the fact that not every current HR professional can be re- or upskilled to become a professional HR analyst even though the expected demand increases (Rasmussen and Ulrich 2015). If the focus is set just on HR processes and knowledge, new non-professional HR analysts might misjudge some activities or processes in their responsibility due to their restricted knowledge about data analytics. Their actions might have far-reaching effects on digital processes and functionality of interconnected systems and services as discussed by Nunan and Di Domenico (2017).

Finding a transitional solution is of high relevance as HR analysis hold promising insights especially on the subsequent levels of mere description, such as competence management and HRD. The field of HR itself can be used as an accurate example: Studies have shown that there is a lack in employees holding both relevant parts of competencies in data analytics and HR knowledge. Moreover, we know that the demand in HR analytics professionals is likely to increase while at the same time not every HR professional or data analyst can be developed into one. A data-driven approach in competence management could be used to identify suitable candidates that are likely to be successful in the new job as HR analysts because they meet relevant cri- 
teria or got the necessary qualifications by ways that are not mentioned in HRIS systems. On this level of analysis also other functions than HR and IT or a different field for the operation of HR analytics can be considered. Since there are no clear responsibilities yet or appropriate expertise either HR and technical professionals must work in interdisciplinary teams to detect blind spots (Jatobá et al. 2019), or HR analytics has to be relocated into an end-toend business analytics unit to be effective (Rasmussen and Ulrich 2015, p. 236). Contrary to those approaches Bassi states that is has to be "HR_-not IT or finance-(that) needs to take the lead on HR analytics" (2015, p. 17), even though that requires new capabilities and a competence shift.

\section{Approaches of HR big data analytics on individual performance}

The core of HR analytics is analysing people data to improve individual and organisational performance. Potential for optimisation can be seen e.g. throughout many fields of HR development: Given the demographic development, lots of valuable knowledge on processes and activities will be lost with the retirement of the baby boomer generation costing organisations valuable time and resources to regain. HR analytics could help preventing the loss of valuable knowledge by collecting successful experts data and aggregating it to develop training measures for newcomers and job starters (Hamilton and Sodeman 2020). Moreover, a strategic data collection of tasks and actions could be used to provide an empirically founded basis for task-based information. Empirical evidence might support experts in identifying relevant tasks on a job (Lievens et al. 2004, p. 886) so that the quality of expert assessments would be improved. A high-quality assignment of relevant tasks on certain jobs combined with detailed skill and competence profiles of employees will likely be beneficial for the allocation of workforce within an organisation. Instead of assigning employees to jobs and tasks driven by a manual match of person and job, professional experience and implicit expertise, HR analytics could improve strategic human capital management to advance in organisational and individual performance (Hamilton and Sodeman 2020). Identifying so called 'knowledge stars' at an early stage and monitoring their set of individual competencies on a deeper level than HRIS can help to identify and monitor crucial and desirable competences on a job as well as suitable developments paths on a bigger scale. Besides detailed task-based information and the identification of successful employees organisations have to make sure that also the relevant implicit knowledge is assessed and considered among data analysis in competence-based use cases. Answering questions about drivers on an individual level has shown to be much easier than finding answers to drivers on an organizational level (Bassi 2015) but if a new understanding of HR analytics beyond operational questions succeeds in finding answers on an organisational level it can add significant strategic value such as an improved organisational strategy, reduced fluctuation and higher employee satisfaction on the job.

\section{Use case-related prerequisites on big data in HR}

HR analytics is just beginning to impact organisational performance while researchers and practitioners already come up with a wide range of use cases. The broad field of possible applications is not fully developed while we can already estimate the huge bandwidth artificial intelligence (AI) in HR offers for further improvement (Jatobá et al. 2019). As Rasmussen and Ulrich (2015) point out, a relevant business use case should be the initial starting point for HR data analytics. Even though the 'hard' KPIs like an increase in output are of huge interest for organisations, the effects of HR analytics, however, go way beyond a mere increase in performance. Besides boosting work-related KPIs HR analytics can further make use of its strategic nature and take influence on company-wide business decisions and support in shaping future business models (Lawler III et al. 2004). Despite the large number of factors that have to be considered for forming an organisational strategy HR analytics can take a vital position if it focuses on the right questions. In the field of competence management for example, there are two possible options in influencing future business models: One option is to take an 'outside-in'-perspective and asking how the environment and respective area of business is likely to develop and how that in return affects competence demands within an organisation. The expected developments are used to create suitable qualification offers and development paths for employees. The second option is to take the 'inside-out'-perspective and ask how maximum use of the available competences can be made. If the field of business is about to change drastically it may be too costly or take too much time to up- and re-skill a large number of employees when at the same time the competencies already available are relevant for the success of a new business model. For this approach to succeed some conditions have to be met: On the one hand, there has to be available data about existing competencies at presence. A reliable set of competencies requires a sound understanding about the character of competence itself, that is often rather located in a broader performance space or in behavioural patterns (Becker et al. 2003; Lievens et al. 2010; Sanchez and Levine 2009; Tett et al. 2000) in contrast to well-defined tasks in job analysis. On the other hand, there has to be an assessment or forecast of competencies that will be relevant in the 
future. The application of data analytics in a competence context can benefit both prerequisites: Data analytics can help to identify similarities that lie behind the successful performance of different tasks as latent constructs and may so far have received no further attention. If this context is considered in further analyses there may be procedures to identify these behavioural patterns as competencies, even though a careful examination and confirmation by experts should be secured. Secondly, if there is a procedure to link successful job tasks to underlying competencies, this approach could also be used to derive competencies from expected future job requirements. A cooperation between HR departments and internal strategy or corporate foresight experts can be helpful to include external developments that may shift job demands. An approach like this sounds promising but at the same time is highly specific for different fields or even jobs and is also dependent from the company-specific culture and wording. The effort that has to be undertaken to gather the relevant data, conduct the analyses, and to project and update the results is not to be underestimated. While Rasmussen and Ulrich (2015) suggest that it might create a higher benefit for the organisation to choose an 'outside-in' point of view we would like to argue that both perspectives should be considered when defining a use case for HR analytics. Even though approaches like corporate foresight continuously improve, a steadily more volatile and complex environment requires taking different perspectives into account.

\section{Developmental signals of big data in HR}

The lack of HR analytic professionals is especially striking as the idea of HR analytics is not exclusively new. Yet, in cross-organisational comparison the results of HR analysts teams often fails to keep up with the impact of other functions and remains below expectations (Rasmussen and Ulrich 2015). This is especially concerning as according to Rasmussen and Ulrich (2015) there is a huge overlap between the topics summed up under HR analytics and familiar HR topics such as personnel economics, utility analysis and evidence-based management. Considering that also some of the most pressing questions HR analytics is trying to address are not new (Cappelli 2017), e.g. how to hire the right people, more research should be conducted to examine how and in how far HR intelligence can create an advance in knowledge to well-known questions. Besides the investigation on already well-known questions there is the field of new possibilities by advanced data analytics on the insight or even predictive analytics level that comes along with increased demands in data. Whereas the idea of recruiting, developing and allocating employees on a data-driven intelligent level sounds promising and time saving, the ex- pertise and quality of data needed is many times higher than on a reporting level. All in all, the field of HR analytics has not been examined carefully yet by science and organisations so that less is known about limitations of insights HR analytics offers and if an investment in building up respective structures will pay off in the future. On the other hand, current literature suggests that if the prerequisites are met HR analytics has wide-ranging potential and advances in competition for those who engage with advanced analytics in data at an early time.

\section{Employee-related preconditions for a successful application of HR big data analytics}

The most crucial factor regarding the implementation of HR analytics on any level are the employees of an organisations and their motives, beliefs and concerns. Calvard and Jeske found that "accidents that reveal personal information about individual employees or employee groups are highly likely to undermine trust, group cohesion and commitment to the employer" (2018, p. 161), which is a hazard in times of human capital as competitive advantage. From the employee perspective a transparent presentation of volume, motive and results of collected data will help understanding the 'bigger picture of HR analytics'. Detailed information on the importance of their work and how individual outcomes have a direct impact on organisational performance can not only enhance the relationship between employees and employer (Hamilton and Sodeman 2020), but also be used for an advanced approach in competence modelling and employee development. If there is a keen understanding of all relevant contributions along the value chain it might help employees to better understand the relevance of their individual skills as well as offering options for future developments and qualifications. HR professionals can use said competence models to maximise person-job fit at the same time as engaging in employee-centred competence development. If the skillset of a person is assessed properly, a higher person-job match as well as offered qualifications can be improved leading to a more holistic competence development approach and reduced fluctuation due to dissatisfaction. Placing the employee and its contribution within the bigger picture will not only empower the employee but will lead to increased organisational performance as well (Hamilton and Sodeman 2020). Intelligent software solutions are constantly increasing in relevance in decision making and our everyday lives (Dickson 2018). It is therefore of fundamental importance for organisations to establish a high competence and trustworthiness in operating with intelligent systems and sensible person-related data such as competence data. 


\section{Ethical implications for the implementation of HR analytics}

Apart from the structural and the psychological level there is a lot of uncertainty regarding ethical implications for HR Analytics and the field of data protection. The uncertainty can partly be attributed to a large neglect of addressing ethical issues regarding big data and organisations at all to this day (Nunan and Di Domenico 2017). As the movement is just beginning to take form, already in the early 2000's Kayes, Stirling, and Nielsen predicted that ethical lapses, data leaks and big data monitoring practices will become relevant topics for research in HR and information management (Kayes et al., 2007). One reason for the volatile situation of big data collection is that the technology to collect and analyse data in multiple ways is growing much faster than organisations and society are able to define what is appropriate in which context and to set up according arrangements and security measures (Bassi 2015). So, "the ethical issues with big data lie not so much with its collection but with the weaknesses in organisational processes and systems that enable it" (Nunan and Di Domenico 2017, p. 26). The best chance to tackle ethical challenges and potential risks seems to be the anticipative implementation of a HR risk management system or at least a contract that clearly defines what techniques are appropriate in which context (Bassi 2015; Calvard and Jeske 2018) and sticking to a simple key requirement: "Big data must be considered in everyone's best interest" (Hamilton and Sodeman 2020 , p. 88). This is especially true for advanced analytics functions as HR or competence development. The data that are considered while setting up development strategies for employees are highly sensible from both a personal and a competitive perspective. Therefore, it should be ensured that personal data is safe from misuse or adverse consequences in cases of a misfit. Organisations have to find a way and processes to ensure employees that sharing competence-related data will never be used to their disadvantage and that the benefits of using individual data for competence development outnumber the risks multiple times.

\section{Requirements in data security}

Ethical implications of exceeding relevance in the context of big HR data also imply questions regarding data security and privacy that shall be addressed shortly. A superficial examination on the principles of data security suggests a contradiction towards the goals of big data in HR. Whereas data minimization is a principle of data security, big HR data tries to collect and process all data available. While from a data security perspective data usage shall be driven towards a specific purpose big HR data strives to bring to- gether data sets from different purposes and reuse them if promising. Already the joint storage of different data sets is in conflict with the separation rule according to data security principles while one of big HR data's primary goals is to derive new insights from the combination of data (for a more detailed elaboration see Strohmeier 2017). One approach to mitigate the sensitivity of big data analysis in HR can be the complete anonymization or pseudonymisation-which in turn excludes various use cases of HR analytics (Strohmeier 2017). This means that in order to benefit from the possibilities advanced analytics hold, organisations have to find a way to ensure the protection of privacy while at the same time analysing data specific enough to give individual recommendations. This task is especially complicated in the field of competence development where the analysed data has to be assigned to an individual in order to be able to give individual development suggestions. Nowadays the competences an employee holds are registered within the educational history in HRIS systems and job descriptions. If organisations strive to also assess competencies employees hold beside those formal sources employees have to cooperate and share additional data on a voluntary basis. There have to be binding rules for both sides that enable a reliable and objective collection of available and recommended competencies. Such an approach was undertaken by the "Deutsche Gesellschaft für Personalführung" (DGFP) in 2018, where a code of conduct for people analytics was introduced (Heuer and Koch 2018). If organisations commit to such conducts and manage to convince employees that sharing data about held competencies a symbiotic relationship can be established. While a holistic assessment of available competencies allows organisations to make better strategic decisions, an individual assessment of an employee's skillset can support an employee-centred competence development and higher person-job fits.

\section{Potential perspectives on HR analytics in competence management}

As descriptive analytics focus on 'hard' KPIs such as number of employees per department, average headcount or average outcome, analytics that are carried out on the level of insight or predictive analytics can lead to major competitive advantages. The procedure of an HR analytics project according to Staritz and Biemann (2018) consists of three major steps:

1. Definition of an appropriate research question. The question should not be too complex so that it is still manageable but at the same time it should also not be too narrow or already suggest solutions to the challenge. Topics 
for appropriate questions can either be gathered in a topdown approach or by surveying relevant stakeholders.

2. The question should then be broken down into measurable concepts. Consequently it should be checked if the required data are already available or if they have to be collected. During this step the cost-benefit-ratio of additional data collection should be considered. While the definition of the question of interest and the interpretation of results should be done within HR departments, the analysis can also be carried out by data experts from different departments.

3. The results and insights gathered should be translated into recommendations for action. In some cases it can be valuable to pilot the measures within a single department before the comprehensive roll-out.

For the field of HRD there are numerous options for beneficial use cases that include a strategic advantage on different levels in different functions. Büchsenschuss and Pettman (2018, p. 36) provide an approach that structures the layers by the level of advancement, starting at 'data foundations, standards \& governance' and moving over 'descriptive analytics \& reporting', 'data exploration' and 'predictive models \& methods' towards 'strategic personnel planning'. The functions of HR can be addressed beginning in the field of recruiting. As the example of Unilever shows, organisations can decrease their processing time of applications by weeks while increasing the amount of matching candidates invited for personal interviews by applying HR analytics (Feloni 2017). For the field of competence management, the authors state that HR analytics can be used to analyse, whether different job demands can be clustered into behavioural patterns or competencies and therefore bridge the gap between job analysis and competence management. Consequently, a solid estimation of available competencies on-site can be mapped to an expected demand in the future gathered through corporate foresight activities and environmental monitoring. Comparing available competence sets to expected shifts in the future and maybe even competitor's profiles can contribute to an organisation's HR strategy. As the HR strategy is not just driven by external developments, but also by internal HRD paths and programmes, HR analytics can help to define competence requirements by comparing data of successful and less successful job-holders to identify relevant competencies and successful patterns of behaviour. If these insights are stored, integrated into a database and maintained, it would be feasible to identify the right people for development paths not only by expert assessment but supported by an intelligent algorithm that can suggest promising candidates. As the case of Nestlé shows, analysing data of employees with similar demographic or behavioural patterns can help to develop suitable qualification paths or incentive systems (Büchsen- schuss and Pettman 2018). Spoken from a data-driven point of view, a smart algorithm is able to detect closeness in standardized contents of different projects or tasks and therefore is able to recommend promising knowledge holders for future operations. Another perspective for big data analytics in competence modelling is the implementation of monitoring systems for new developments in certain competence fields. A successful implementation of HR analytics and realisation of recommendations gained through data analysis can help players on the global market to "not only outperform their contenders, but also profit higher value to shareholders and be in a better placed to meet workforce and business demands for the future" (Momin and Mishra 2015, p. 259).

Yet, HR analytics is rather used on a descriptive reporting level. To keep up with the challenges brought to organisations by technological advancement and to meet the expectations of shareholders HR analytics has to exceed the descriptive level and establish itself on the conceptual level. Especially fields like competence management would profit from an approach that focuses on measurable and verifiable assumptions that were made based on data monitoring instead of operative KPIs. Learning monitoring systems can provide HR departments with new developments in different areas, provide a link to the competence level and consider various characteristics for suggestions in hindsight to employee development and allocation. Nevertheless, data analytics on a profound individual level requires a strong trust in the system and its users. Further research can help evaluating the status quo in HR analytics and to set up guidelines for technology within the field of HR (Jatobá et al. 2019).

\section{Conclusion}

The conceptual field of HR analytics is characterized by novelty, a high degree of uncertainty and emotional debates about the borders between opportunity and adequacy. While HR analytics seems to stand in strong contradiction to values in regard of personal data management it also offers benefits for individuals who agree to share their data. Given the findings from literature research and the characteristics of the current debate an application of Gartner's Hype Cycle (Fenn and Linden 2003) on big data in HR would suggest an early stage that is characterised by strongly diverging opinions and expectations (Strohmeier 2017). While there is a high uncertainty within future developments and consequences in HR analytics an early adoption could either secure competitive advantage and market share or result in high expenses for a system that does not deliver the desired strategically relevant insights for one out of numerous reasons. This is also displayed by the apparent contradiction 
between the large amount of benefits HR promises and the small number of organisations that have undergone efforts in order to implement HR analytics (Deloitte 2017; Marler and Boudreau 2017). To convince managers, decision makers and employees about the benefits HR analytics can deliver, there are a number of questions that have to be examined by practice and science commonly e.g. what kind of organisational questions can be answered by HR analytics, what kind of data is needed to achieve the desired insights and how data misuse can be prevented.

As many organisations recognise the relevance of data analytics in HR, only few of them dispose the data that is necessary in order to carry out appropriate analysis. At the same time, when it comes to data analysis it is 'quality over quantity'. As the introduction of overfit within big data analysis has shown a larger sample of data can rather lead to incorrect interpretations than generating additional advance in knowledge. This is especially relevant for HR analytics, where more data can promote opaqueness and wrong conclusions instead of increasing the amount of useful insights generated (Calvard and Jeske 2018). Understanding which data is needed might help organisations to handle the fuzzy term of HR analytics and takes into account data privacy principles. Future research should therefore examine the question what kind of data adds insights to what kind of questions.

Secondly, a reason for the low number of organisations engaging in HR analytics is the opaqueness of the field. Future research could create benefits by examining, if there is a kind of exemplary set-up or a sample process when implementing HR analytics. A clear idea of necessary steps to be undertaken would help practitioners to deal with the decision of implementation and enable scientists to explore effects and interplays of the different steps, revealing room for optimisation and improved methods.

On the other hand, HR analytics holds promising outlooks for those who can realise a successful implementation and management. The value to be gained increases with the complexity of data analysis. The latest prominence of big data analytics in various fields indicates that data is the key to success in a digitalised world. Those who neglect the impact of data analytics on market position are likely to be left behind in global competition. The decision whether to implement big data analytics is complicated by the fact that machine learning is a relatively new field in the organisational context, so that yet only little is known about mechanisms of action. Intelligent systems provide solutions, but only few (if at all) can see if and what effects different variables have within the analysis (Stachl and Bühner 2018). To meet the claim for maximised transparency, future research should emphasise on validating digital operations and understanding the cause-effect-relationships of such systems. Especially as the field of HR analytics handles sensible sub- jects and includes highly sensible data the need to find answers to the open questions is pressing while the willingness to experiment is little. As guidelines for data privacy are not globally consistent, international organisations might pilot HR analytics in countries with lower regulations, like India or the USA (Staritz and Biemann 2018). Still, it is of global interest to evaluate the first steps that are taken in HR analytics carefully on a scientific and a practical level and establish guidelines for a sound implementation. Organisations who have already implemented HR analytics, e.g. Nestlé or Unilever, might possess data that contain valuable insights about the proportion of discharge that HR analytics can provide for certain HR functions or tasks and where fields of promising symbiosis are beginning to form. All in all, as the field of HR analytics is just emerging, it provides a variety of benefits that are linked to a just as large number of questions that have to be examined by further research if the whole potential should be unleashed.

Funding Open Access funding enabled and organized by Projekt DEAL.

Open Access This article is licensed under a Creative Commons Attribution 4.0 International License, which permits use, sharing, adaptation, distribution and reproduction in any medium or format, as long as you give appropriate credit to the original author(s) and the source, provide a link to the Creative Commons licence, and indicate if changes were made. The images or other third party material in this article are included in the article's Creative Commons licence, unless indicated otherwise in a credit line to the material. If material is not included in the article's Creative Commons licence and your intended use is not permitted by statutory regulation or exceeds the permitted use, you will need to obtain permission directly from the copyright holder. To view a copy of this licence, visit http://creativecommons.org/licenses/by/4. $0 /$.

\section{References}

Apt, W., Bovenschulte, M., Hartmann, E.A., \& Wischmann, S. (2016). Foresight-Studie „Digitale Arbeitswelt“: für das Bundesministerium für Arbeit und Soziales. Berlin. https://www. bmas.de/DE/Service/Medien/Publikationen/Forschungsberichte/ Forschungsberichte-Arbeitsmarkt/fb-463-digitale-arbeitswelten. html. Accessed 1 Nov 2018.

Arnold, R. (2010). Qualifikation. In R. Arnold, S. Nolda \& E. Nuissl (Eds.), Wörterbuch Erwachsenenbildung 2nd edn. (Vol. 8425, pp. 251-252). Stuttgart: UTB.

Arntz, M., Gregory, T., Jansen, S., \& Zierahn, U. (2016). Tätigkeitswandel und Weiterbildungsbedarf in der digitalen Transformation. Mannheim. http://ftp.zew.de/pub/zew-docs/gutachten/Digitale TransformationAcatechIKT2016.pdf. Accessed 27 Oct 2018.

Asgarian, C., \& Feuersinger, N. (2017). Strategische Personalplanung. In W. Jochmann, I. Böckenholt \& S. Diestel (Eds.), HR-Exzellenz (pp. 289-306). Wiesbaden: Springer. https://doi.org/10.1007/9783-658-14725-9_17.

Ballot, G., Fakhfakh, F., \& Taymaz, E. (2006). Who benefits from training and R\&D, the firm or the workers? British Journal of Industrial Relations, 44(3), 473-495. https://doi.org/10.1111/j. 1467-8543.2006.00509.x.

Bassi, L. (2015). Raging debates in HR analytics. People \& Strategy, 34(2), 14-18. 
Becker, M. (2009). Personalentwicklung: Bildung, Förderung und Organisationsentwicklung in Theorie und Praxis (5th edn.). Stuttgart: Schäffer-Poeschel.

Becker, M. (2011). Systematische Personalentwicklung: Planung, Steuerung und Kontrolle im Funktionszyklus (2nd edn.). Stuttgart: Schäffer-Poeschel. http://site.ebrary.com/lib/alltitles/docDetail. action?docID=10555951

Becker, B.E., Huselid, M. A., \& Ulrich, D. (2003). The HR scorecard: Linking people, strategy, and performance (Nachdr). Boston: Harvard Business School Press.

Benko, C., \& Volini, E. (2014). What it will take to fix HR. https://hbr. org/2014/07/what-it-will-take-to-fix-hr. Accessed 8 Feb 2020.

Berger, T., \& Frey, C.B. (2016). Digitalization, jobs, and convergence in europe: strategies for closing the skill gap. https://www. oxfordmartin.ox.ac.uk/downloads/reports/SCALE_Digitalisation_ Final.pdf. Accessed 1 Nov 2018.

Berthel, J., \& Becker, F. G. (2010). Personal-Management: Grundzüge für Konzeptionen betrieblicher Personalarbeit (9th edn.). Stuttgart Schäffer-Poeschel.

Boudreau, J., \& Cascio, W. (2017). Human capital analytics: why are we not there? Journal of Organizational Effectiveness: People and Performance, 4(2), 119-126. https://doi.org/10.1108/JOEPP-032017-0021.

Braun, S., Schmidt, A.P., \& Graf, U. (2008). Parzitipative Entwicklung von Kompetenzontologien. Conference: Workshop Nutzerinteraktion im Social Semantic Web, Mensch \& Computer, 8. Fachuebergreifende Konferenz-M\&C 2008. https://www.researchgate.net/ publication/229422951_Partizipative_Entwicklung_von_Kompe tenzontologien. Accessed 4 Oct 2019.

Büchsenschuss, R., \& Pettman, J. (2018). Entscheidungen: People Analytics bei Nestlé. Personalführung. (5), 34-39. https://www.dgfp. de/fileadmin/user_upload/DGFP_e.V/Medien/Personalfuehrung/ Ausgaben_2018/05/PF0518_SoMe.pdf. Accessed 11 Feb 2020.

Butschan, J., Nestle, V., Munck, J.C., \& Gleich, R. (2017). Kompetenzaufbau zur Umsetzung von Industrie 4.0 in der Produktion. In M. Seiter, L. Grünert \& S. Berlin (Eds.), Betriebswirtschaftliche Aspekte von Industrie 4.0 (pp. 75-110). Wiesbaden: Springer.

Calvard, T.S., \& Jeske, D. (2018). Developing human resource data risk management in the age of big data. International Journal of Information Management, 43, 159-164. https://doi.org/10.1016/j. ijinfomgt.2018.07.011.

Campion, M. A., Fink, A. A., Ruggeberg, B. J., Carr, L., Phillips, G. M., \& Odman, R. B. (2011). Doing competencies well: best pracitces in competency modelling. Personnel Psychology, 64(1), 225-262. https://doi.org/10.1111/j.1744-6570.2010.01207.x.

Cappelli, P. (2017). There's no such thing as big data in HR. https://hbr. org/2017/06/theres-no-such-thing-as-big-data-in-hr. Accessed 8 Feb 2020

Cascio, W.F., \& Boudreau, J.W. (2015). Investing in people: financial impact of human resource initiatives (2nd edn.). Upper Saddle River: FT Press.

Crosman, P. (2018). Facing up to bias in facial recognition. https:// www.americanbanker.com/news/facing-up-to-bias-in-facialrecognition. Accessed $5 \mathrm{Feb} 2020$

Decius, J., \& Schaper, N. (2017). The competence management tool (CMT) - A new instrument to manage competences in small and medium-sized manufacturing enterprises. Procedia Manufacturing, 9, 376-383. https://doi.org/10.1016/j.promfg.2017.04.041.

Deloitte (2017). Deloitte global human capital trends: rewriting the rules for the digital age. https://www2.deloitte.com/content/dam/ Deloitte/de/Documents/human-capital/HC-Trends\%20Studie2017-Global-Human-Capital-Trends-US.pdf. Accessed 5 Feb 2020.

Deloitte (2019). Deloitte global human capital trends: reinvent with a human focus. https://www2.deloitte.com/be/en/pages/humancapital/articles/human-capital-trends-2019.html. Accessed $5 \mathrm{Feb}$ 2020 .
Dickson, B. (2018). What is algorithmic bias? https://bdtechtalks.com/ 2018/03/26/racist-sexist-ai-deep-learning-algorithms/. Accessed $11 \mathrm{Feb} 2020$.

Dirks, T. (2016). Neue Arbeit: Wie Digitalisierung unsere Jobs verändert

Eliott, T. (2013). Analytics moves to the core. https://timoelliott.com/ blog/2013/02/gartnerbi-emea-2013-part-1-analytics-moves-tothe-core.html. Accessed 11 Feb 2020.

Erpenbeck, J., \& v. Rosenstiel, L. (2005). Kompetenz: Modische Worthülse oder innovatives Konzept? Wirtschaftspsychologie aktuell, 3, 39-42. https://www.wirtschaftspsychologie-aktuell.de/ Material_3_2005/wp_03_2005_39.pdf.

Erpenbeck, J., Heyse, V., Meynhardt, T., \& Weinberg, J. (2007). Die Kompetenzbiographie: Wege der Kompetenzentwicklung (2nd edn.). Münster: Waxmann. http://www.content-select.com/ index.php?id=bib_view\&ean $=978383096808$

Feloni, R. (2017). Consumer-goods giant Unilever has been hiring employees using brain games and artificial intelligence-and it's a huge success. https://www.businessinsider.com/unileverartificial-intelligence-hiring-process-2017-6? $\mathrm{r}=\mathrm{DE} \& \mathrm{IR}=\mathrm{T}$. Accessed 8 Feb 2020.

Fenn, J., \& Linden, A. (2003). Understanding Gartner's hype cycles. Strategic analysis report, R-20-1971. (pp. 88-100).

Foundation, S.H.R.M. (2016). Using workforce analytics for competetive advantage. Shaping the future of HR. https://www.shrm. org/about-shrm/press-room/press-releases/pages/2016-use-ofanalytics-survey.aspx. Accessed 7 Feb 2020.

Fredersdorf, F., \& Glasmacher, B. (2010). Etappe 6: Weiterbildungsmanagement. In M.T. Meifert (Ed.), Strategische Personalentwicklung (pp. 244-289). Berlin, Heidelberg: Springer. https:// doi.org/10.1007/978-3-642-04401-4_10.

Frey, C. B., \& Osborne, M. A. (2013). The Future of Employment: How Susceptible are Jobs to Computerisation? Retrieved from Oxford University website. https://www.oxfordmartin.ox.ac.uk/ downloads/academic/The_Future_of_Employment.pdf. Accessed 10 Feb 2020

Hamilton, R. H., \& Sodeman, W. A. (2020). The questions we ask: opportunities and challenges for using big data analytics to strategically manage human capital resources. Business Horizons, 63(1), 85-95. https://doi.org/10.1016/j.bushor.2019.10.001.

Hammermann, A., \& Stettes, O. (2015). Fachkräftesicherung im Zeichen der Digitalisierung: Empirische Evidenz auf Basis des IWPersonalpanels 2014. Gutachten. Köln. https://www.bmwi.de/ Redaktion/DE/Downloads/F/fachkraeftesicherung-im-zeichender-digitalisierung.pdf?_blob $=$ publicationFile $\& v=4$. Accessed 1 Nov 2018.

Heuer, K., \& Koch, J. (2018). Schöne neue Welt: ein Trend wird Wirklichkeit. Personalführung. (5), 26-27. https://www.dgfp. de/fileadmin/user_upload/DGFP_e.V/Medien/Personalfuehrung/ Ausgaben_2018/05/PF0518_SoMe.pdf. Accessed 4 Feb 2020.

Janssen, S., \& Leber, U. (2015). Weiterbildung in Deutschland: Engagement der Betriebe steigt weiter (IAB-Kurzbericht No. 13). http://doku.iab.de/kurzber/2015/kb1315.pdf. Accessed 1 Nov 2018.

Jatobá, M., Santos, J., Gutierriz, I., Moscon, D., Fernandes, P.O., \& Teixeira, J.P. (2019). Evolution of artificial intelligence research in human resources. Procedia Computer Science, 164, 137-142. https://doi.org/10.1016/j.procs.2019.12.165.

Jochmann, W. (2006). Retention Management - die Leistungsträger der Unternehmung binden. In H.-C. Riekhof (Ed.), Strategien der Personalentwicklung (pp. 173-190). Wiesbaden: Gabler. https://doi.org/10.1007/978-3-8349-9178-2_12.

Kagermann, H. (2014). Chancen von Industrie 4.0 nutzen. In T. Bauernhansl, M. ten Hompel \& B. Vogel-Heuser (Eds.), Industrie 4.0 in Produktion, Automatisierung und Logistik (pp. 603-614). Wiesbaden: Springer. https://doi.org/10.1007/978-3-658-04682-8_31.

Kauffeld, S., \& Grote, S. (2019). Personalentwicklung. In S. Kauffeld (Ed.), Arbeits-, Organisations- und Personalpsychologie für 
Bachelor (pp. 167-210). Berlin, Heidelberg: Springer. https://doi. org/10.1007/978-3-642-42065-8.

Kauffeld, S., \& Paulsen, H.F.K. (2018). Kompetenzmanagement in Unternehmen: Kompetenzen beschreiben, messen, entwicklen und nutzen (1st edn.). Arbeits-, Organisations- und Wirtschaftspsychologie. Stuttgart: Kohlhammer. https://ebookcentral.proquest. com/lib/gbv/detail.action?docID=5392206

Kayes, D. C., Stirling, D., \& Nielsen, T. M. (2007). Building organizational integrity. Business Horizons, 50(1), 61-70. https://doi.org/ 10.1016/j.bushor.2006.06.001.

Klimecki, R., \& Gmür, M. (2005). Personalmanagement: Strategien, Erfolgsbeiträge, Entwicklungsperspektiven (3rd edn.). Grundwissen der Ökonomik Betriebswirtschaftslehre, Vol. 2025. Stuttgart: Lucius \& Lucius.

Kortsch, T., Paulsen, H.F. K., \& Kauffeld, S. (2018). Unterstützungskultur trifft auf digitale Lösungen: Kompetenzentwicklung mit dem KOMPETENZNAVI optimieren. In S. Kauffeld \& F. Frerichs (Eds.), Kompetenzmanagement in kleinen und mittelständischen Unternehmen (pp. 181-193). Berlin, Heidelberg: Springer. https://static-content.springer.com/pdf/chp\%3A10.1007 \%2F978-3-662-54830-1_11.pdf?token=1582878316314-$8615 \mathrm{e} 8 \mathrm{e} 2512 \mathrm{e} 57 \mathrm{a} 961 \mathrm{f} 8688 \mathrm{c} 431206433493297 \mathrm{da} 7 \mathrm{c} 37$ c6ebc91360fa04c7f0f258febbc00a8cdaaad0b2b56776 a0a5961c2661acfa43a090dd8f05c57ea4e1e.

Kortsch, T., Paulsen, H.F. K., Naegele, L., Frerichs, F., \& Kauffeld, S. (2016). Branchentrends und Betriebskultur als Basis strategischer Kompetenzentwicklung. Personal Quarterly, 68(02), 16-21. https://www.haufe.de/download/personalquarterly-22016kompetenznutzung-personalquarterly-348532.pdf.

Lawler III, E. E., Levenson, A., \& Boudreau, J. W. (2004). HR metrics and analytics: uses and impacts. Center for Effective Organizations, 27(4), 27-35. https://pdfs.semanticscholar.org/928e/ c09b9509f01607514f3746ae59db8ce61e84.pdf.

Levenson, A. (2018). Using workforce analytics to improve strategy execution. Human Resource Management, 57(3), 685-700. https://doi.org/10.1002/hrm.21850.

L'Heureux, A., Grolinger, K., Elyamany, H.F., \& Capretz, M.A.M. (2017). Machine learning with big data: challenges and approaches. IEEE Access, 5, 7776-7797. https://doi.org/10.1109/ ACCESS.2017.2696365.

Lievens, F., Sanchez, J. I., Bartram, D., \& Brown, A. (2010). Lack of consensus among competency ratings of the same occupation: noise or substance? The Journal of Applied Psychology, 95(3), 562-571. https://doi.org/10.1037/a0018035.

Lievens, F., Sanchez, J. I., \& de Corte, W. (2004). Easing the inferential leap in competency modelling: the effects of task-related information and subject matter expertise. Personnel Psychology, 57(4), 881-904. https://doi.org/10.1111/j.1744-6570.2004.00009.x.

Marler, J.H., \& Boudreau, J.W. (2017). An evidence-based review of HR Analytics. The International Journal of Human Resource Management, 28(1), 3-26. https://doi.org/10.1080/09585192. 2016.1244699.

McClelland, D. C. (1973). Testing for competence rather than for "intelligence". The American Psychologist, 28(1), 1-14. https://doi. org/10.1037/h0034092.

McIver, D., Lengnick-Hall, M.L., \& Lengnick-Hall, C. A. (2018). A strategic approach to workforce analytics: Integrating science and agility. Business Horizons, 61(3), 397-407. https://doi.org/10. 1016/j.bushor.2018.01.005.

Michaels, E., Handfield-Jones, H., \& Axelrod, B. (2001). The war for talent. Boston, Mass.: Harvard Business School Press.

Mietzner, D., Hartmann, F., \& Fahrenkrug, M. (2017). Szenariobasierte Geschäftsmodellentwicklung als Ansatz der strategischen Vorausschau in kleinen und mittleren Unternehmen: Ein Leitfaden. In Prokom 4. 0 (Ed.), Facharbeit und Digitalisierung: Ergebnisse aus dem BMBF-Verbundprojekt „,Kompetenzmanagement für die
Facharbeit in der High-Tech-Industrie" (pp. 130-131). Bottrop/ Duisburg/Erkrath/Flensburg/Rheine/Rostock/Wildau. Retrieved from https://www.prokom-4-0.de/downloads/instrumente-zumkompetenzmanagement.

Momin, W. Y. M., \& Mishra, K. (2015). HR analytics as a strategic Workforce planning. International Journal of Applied Research, 1(4), 258-260.

Müller, N. A.S. (2005). Die Wirkung innovationsorientierter Kooperationsnetzwerke auf den Innovationserfolg: Eine empirische Untersuchung auf Basis des Competence-Based View und des Relational View. Dissertation. Bremen: Universität Bremen. http:// elib.suub.uni-bremen.de/diss/docs/00010814.pdf

Müller, S. (2006). Methodisches Erfinden im Personalmanagement: Erfolgreiche Anpassung TRIZ-basierter Werkzeuge (1st edn.). Gabler Edition Wissenschaft Forschungs-/Entwicklungs-/ Innovations-Management. Wiesbaden: Deutscher UniversitätsVerlag. https://doi.org/10.1007/978-3-8350-9357-7. Zugl.: Bremen, Univ., Diss., 2006

Müller, A. W., \& Müller-Stewens, G. (2009). Strategic Foresight: Trend- und Zukunftsforschung in Unternehmen - Instrumente, Prozesse, Fallstudien. Stuttgart: Schäffer-Poeschel Verlag für Wirtschaft Steuern Recht GmbH.

Nienaber, C. (2007). Die Bedeutung des Kompetenzmanagements für die strategische Personalarbeit. In W. Jochmann \& S. Gechter (Eds.), Strategisches Kompetenzmanagement (pp. 25-46). Berlin, Heidelberg: Springer. https://doi.org/10.1007/978-3-540-686057_2.

Nunan, D., \& Di Domenico, M. (2017). Big data: a normal accident waiting to happen? Journal of Business Ethics, 145(3), 481-491. https://doi.org/10.1007/s10551-015-2904-x.

Oberländer, M., Beinicke, A., \& Bipp, T. (2020). Digital competencies: a review of the literature and applications in the workplace. Computers \& Education, 146, 1-13. https://doi.org/10.1016/j. compedu.2019.103752.

Patscha, C., Glockner, H., Störmer, E., \& Klaffke, T. (2017). Kompetenz- und Qualifizierungsbedarfe bis 2039: Ein gemeinsames Lagebild der Partnerschaft für Fachkräfte

Paulsen, H.F.K., \& Kauffeld, S. (2019). Kompetenzmanagement in Organisationen: Ein Beitrag zur Laufbahnentwicklung. In S. Kauffeld \& D. Spurk (Eds.), Handbuch Karriere und Laufbahnmanagement. Springer Reference Psychologie. (pp. 511-542). Berlin, Heidelberg: Springer.

Rasmussen, T., \& Ulrich, D. (2015). Learning from practice: How HR analytics avoids being a management fad. Organizational Dynamics, 44(3), 236-242. https://doi.org/10.1016/j.orgdyn.2015. 05.008 .

Reuters (2018). Amazon ditched AI recruiting tool that favored men for technical jobs: Specialists had been building computer programs since 2014 to review résumés in an effort to automate the search process. https://www.theguardian.com/technology/ 2018/oct/10/amazon-hiring-ai-gender-bias-recruiting-engine. Accessed 11 Feb 2020.

Sanchez, J. I., \& Levine, E. D. (2006). The Analysis of Work in the 20th and 21 st Centuries. In N. Anderson (Ed.), Personnel psychology. Handbook of industrial, work and organizational psychology, (Vol. 1, pp. 71-89). London: SAGE. http://www.maorhan.com/ wp-content/uploads/2014/11/0761964886-Psychology-Volume1.pdf.

Sanchez, J. I., \& Levine, E. L. (2009). What is (or should be) the difference between competency modeling and traditional job analysis? Human Resource Management Review, 19(2), 53-63. https://doi. org/10.1016/j.hrmr.2008.10.002.

Sanchez, J.I., \& Levine, E. L. (2012). The rise and fall of job analysis and the future of work analysis. Annual Review of Psychology, 63, 397-425. https://doi.org/10.1146/annurev-psych-120710100401. 
Sauter, W., \& Staudt, F.-P. (2016). Strategisches Kompetenzmanagement 2.0. Wiesbaden: Springer.

Schelten, A. (2004). Einführung in die Berufspädagogik (3rd edn.). Pädagogik. Stuttgart: Steiner.

Scherer, J. (2002). Personalkonzepte für die Beschaffung bei der Henkel KGaA. In D. Hahn \& L. Kaufmann (Eds.), Handbuch Industrielles Beschaffungsmanagement (pp. 973-986). Wiesbaden: Gabler. https://doi.org/10.1007/978-3-663-01582-6_51.

Schlick, C. M., Bruder, R., \& Luczak, H. (2010). Arbeitswissenschaft. Berlin, Heidelberg: Springer.

Schmidt, A.P., \& Kunzmann, C. (2006). Towards a human resource development ontology for combining competence management and technology-enhanced Workplace learning. On the Move to Meaningful Internet Systems 2006: OTM 2006 Workshops: OTM Confederated International Workshops and Posters, AWeSOMe, CAMS, COMINF, IS, KSinBIT, MIOS-CIAO, MONET, OnToContent, ORM, PerSys, OTM Academy Doctoral Consortium, RDDS, SWWS, and SeBGIS 2006,. (Proceedings Part II). (pp. 1078-1087). https://www.researchgate.net/publication/ 220831141_Towards_a_Human_Resource_Development_ Ontology_for_Combining_Competence_Management_and_ Technology-Enhanced_Workplace_Learning

Scholz, C. (2018). Zukünftige Herausforderungen in der Personalentwicklung und die sich daraus ergebenden neuen Rollen: Den Wettbewerbsvorsprung durch ein neues Verständnis von Personalentwicklung sichern. In B. Covarrubias Venegas, K. Thill \& J. Domnanovich (Eds.), Personalmanagement (pp. 411-432). Wiesbaden: Springer.

Singer, N., \& Metz, C. (2019). Many facial-recognition systems are biased, says U.S. study: algorithms falsely identified AfricanAmerican and Asian faces 10 to 100 times more than caucasian faces, researchers for the national institute of standards and technology found. https://www.nytimes.com/2019/12/19/technology/ facial-recognition-bias.html. Accessed 11 Feb 2020.

Smith, A. (2016). Public predictions for the future of workforce automation. http://www.pewresearch.org/wp-content/uploads/sites/ 9/2016/03/PI_2016.03.10_Workforce-Automation_FINAL.pdf. Accessed 8 Nov 2018.

Solga, M., Ryschka, J., \& Mattenklott, A. (2011). Personalentwicklung: Gegenstand, Prozessmodell, Erfolgsfaktoren. In J. Ryschka, M. Solga \& A. Mattenklott (Eds.), Praxishandbuch Personalentwicklung: Instrumente, Konzepte, Beispiele (3rd edn., pp. 19-34). Wiesbaden: Springer.

Stachl, C., \& Bühner, M. (2018). Maschinelle Lernverfahren kontra Persönlichkeitstests: Big Data und Persönlichkeit. Personalführung, 5, 22-33.

Staritz, S., \& Biemann, T. (2018). Hype oder Kurswechsel in HR? Nutzen von People Analytics. Personalführung. (5). https://www. dgfp.de/fileadmin/user_upload/DGFP_e.V/Medien/Personalfueh rung/Ausgaben_2018/05/PF0518_SoMe.pdf. Accessed $11 \mathrm{Feb}$ 2020.

Strohmeier, S. (2017). Big HR Data: Konzept zwischen Akzeptanz und Ablehnung. In W. Jochmann, I. Böckenholt \& S. Diestel (Eds.), HR-Exzellenz (pp. 339-355). Wiesbaden: Springer.

Tett, R. P., Guterman, H. A., Bleier, A., \& Murphy, P. J. (2000). Development and content validation of a "hyperdimensional" taxonomy of managerial competence. Human Performance, 13(3), 205-251. https://doi.org/10.1207/S15327043HUP1303_1.

Tewes, U., \& Wildgrube, K. (2016). Psychologie-Lexikon (2nd edn.). Berli, Boston: De Gruyter. https://ebookcentral.proquest.com/lib/ gbv/detail.action?docID $=5049297$

Vogler-Ludwig, K., Kriechel, B., \& Düll, N. (2016). Arbeitsmarkt 2030 - Wirtschaft und Arbeitsmarkt im digitalen Zeitalter:
Prognose 2016. Bielefeld: wbv. http://www.oapen.org/search? identifier $=640936$

Vonken, M. (2006). Qualifizierung versus Kompetenzentwicklung: Schwierigkeiten mit dem Kompetenzbegriff. In P. Gonon, F. Klauser \& R. Nickolaus (Eds.), Kompetenz, Qualifikation und Weiterbildung im Berufsleben. Herbsttagung der Sektion Berufs- und Wirtschaftspädagogik der Deutschen Gesellschaft für Erziehungswissenschaft (DGfE) 2005, Erfurt. Schriftenreihe der Sektion Berufs- und Wirtschaftspädagogik der Deutschen Gesellschaft für Erziehungswissenschaft (DGfE). (pp. 11-25). Opladen: Budrich.

Waller, M. A., \& Fawcett, S.E. (2013). Data science, predictive analytics, and big data: a revolution that will transform supply chain design and management. Journal of Business Logistics, 34(2), 77-84. https://doi.org/10.1111/jbl.12010.

Wildgrube, M. (2018). Kompetenzen in der Beschaffung. Wiesbaden: Springer.

World Economic Forum (2016). The future of jobs: employment, skills and workforce strategy for the fourth industrial revolution. Global Challenge Insight Report. Geneva: World Economic Forum. http://www3.weforum.org/docs/WEF_Future_of_Jobs. pdf

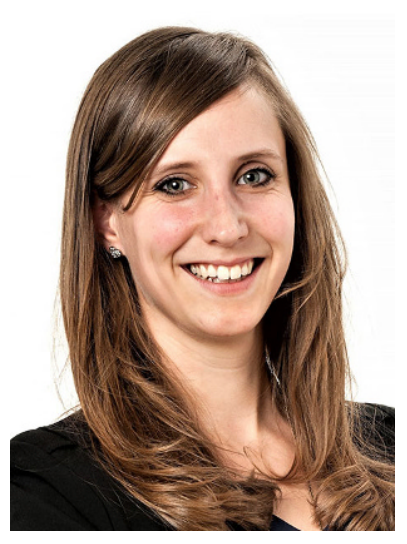

Laura Johanna Karwehl studierte Wirtschaftspsychologie an der Leuphana Universität Lüneburg (B.Sc.) und absolvierte ihren M.Sc. in Psychologie an der Universität Koblenz-Landau. Seit 2018 promoviert sie bei der Volkswagen AG und an der TU Braunschweig zum Thema „Advanced Competence Intelligence: Identifikation datengetriebener Ansätze zur Vorhersage von Zukunftskompetenzen“. Bei der Volkswagen AG ist sie Mitglied der Abteilung für Zukunftsforschung und beschäftigt sich insbesondere mit den Themen Umfeldanalyse und Zukunftskompetenzen.

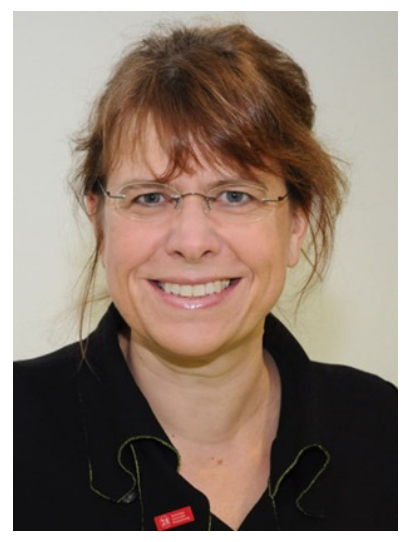

Prof. Dr. Simone Kauffeld ist Inhaberin des Lehrstuhls für Arbeit-, Organisations- und Sozialpsychologie der Technischen Universität Braunschweig. In ihrer Forschungstätigkeit setzt sie sich in zahlreichen Projekten mit den Themen Kompetenzentwicklung und -management (Training und Transfer), Team und Führung, Karriere/Coaching sowie Veränderungen in Organisation und Arbeit auseinander. Das Thema Digitalisierung ist als Querschnittsthema präsent. Als Herausgeberin hat sie die Zeitschriften „PersonalQUARTERLY“ und „Gruppe. Interaktion. Organisation“ neu aufgesetzt und gibt Buchreihen zur Arbeits- und Organisationspsychologie heraus. Um aktiven Wissenstransfer zu leisten, hat sie 2008 die 4A-SIDE GmbH gegründet, die psychologische Expertise mit IT-Kompetenz verbindet. 